\title{
ANALISIS NILAI INDEKS KEHIJAUAN (NDVI) PADA POLA RUANG KOTA AMBON, PROVINSI MALUKU.
}

\author{
ANALYSIS OF NORMALIZED DIFFERENCE VEGETATION INDEX (NDVI) \\ IN AMBON CITY SPATIAL PATTERN, MALUKU PROVINCE.
}

Jan Willem Hatulesila ${ }^{1)}$, Gun Mardiatmoko ${ }^{2)}$, Irwanto Irwanto ${ }^{3)}$

Jurusan Kehutanan Fakultas Pertanian Universitas Pattimura Ambon

Jl. Ir. M. Putuhena, Kampus Poka Ambon 97233

Email:janhatulesila@gmail.com

\begin{tabular}{|l|l}
\hline Diterima: 23 Januari 2019 & Disetujui: 8 Februari 2019
\end{tabular}

\begin{abstract}
Abstrak
Ruang Terbuka Hijau (RTH) merupakan komponen lansekap yang sangat mempengaruhi udara perkotaan baik langsung maupun tidak langsung. Standar ideal luasan minimum ruang terbuka hijau yakni minimal $30 \%$ dari total luas kota. Penelitian dilakukan dengan metode analisis spasial melalui pendekatan perhitungan Nilai Indeks tingkat kehijauan (NDVI) untuk tutupan vegetasi. Analisis terhadap penampalan (overlay) peta SIG tutupan vegetasi dengan peta pola ruang Kota Ambon menghasilkan peta model keruangan RTH kota yang menyajikan gambaran existing corridor pola ruang terbuka hijau, pola ruang terbangun dan pola ruang tidak bervegetasi (lahan kosong). Hasil analisis terhadap peta model keruangan RTH merekomendasikan adanya kawasan dengan areal taman kota, areal spot-spot pertamanan dan areal koridor pepohonan yang ditanam di kiri kanan jalan. Metode inventarisasi, analisis spasial dan observasi dilakukan pada sembilan lokasi sampling, menunjukan bahwa lokasi RTH Kota Ambon seluas $\pm 1.115 .900 \mathrm{~m}^{2}$ atau 111,59 ha, dengan tutupan vegetasi tumbuhan bawah (rerumputan dan pancang) 16,31 ha. Estimasi kandungan karbon vegetasi tumbuhan bawah (rerumputan dan pancang) $52,49 \mathrm{~kg} / \mathrm{ha}$ dan vegetasi tingkat tiang dan pohon 883 $\mathrm{kg} / \mathrm{ha}$. Nilai indeks tingkat kehijauan (NDVI) pada sembilan lokasi sampling RTH Kota Ambon untuk luas tutupan vegetasi adalah 61,58 ha atau $58,31 \%$, kawasan terbangun 39,63 ha atau $37,52 \%$ dan lahan kosong 4,40 ha atau $4,17 \%$
\end{abstract}

Kata Kunci: Indeks Kehijauan (NDVI), Pola Ruang Kota Ambon

\begin{abstract}
Green Open Space is a component of landscaping that greatly affects urban air both directly and indirectly. The ideal standard minimum area of green open space is at least $30 \%$ of the total area of the city.The study used a spatial analysis method through the approach to calculating the Normalized Difference Vegetation Index (NDVI) for vegetation cover. Overlay analysis of GIS vegetation cover maps with the Ambon city spatial pattern map, has produced a map of the city green open spatial model, which shows a picture of existing corridors of green open space patterns, building spatial patterns, and non-vegetation spatial patterns (vacant land).The results of the analysis of the green open space model map recommend the need for areas with urban park areas, park spots areas, and tree corridor areas planted on either side of the road. Inventory method, analysis of spatial and observations carried out at nine sampling locations, showed that the location of Ambon City's green open space was $\pm 1.115 .900 \mathrm{~m}^{2}$ or 111,59 ha, with cover of understorey vegetation (grasses and saplings) 16,31 ha. Estimated carbon content of understorey vegetation (grasses and saplings) 52,49 $\mathrm{kg} / \mathrm{ha}$ and $883 \mathrm{~kg} / \mathrm{ha}$ of pole and tree vegetation. Normalized Difference Vegetation Index (NDVI) in nine sampling locations of Ambon City's green open space, for the area of vegetation cover is 61.58 ha or $58.31 \%$, building area 39.63 ha or $37.52 \%$ and vacant land 4.40 ha or $4.17 \%$.
\end{abstract}

Keywords: Normalized Difference Vegetation Index (NDVI), Ambon City Spatial Pattern 


\section{PENDAHULUAN}

Ruang terbuka kota, ruang hijau kota, mempunyai manfaat keseimbangan alam terhadap struktur kota. Ruang terbuka hijau (RTH) janganlah dianggap sebagai lahan yang tidak efisien, atau tanah cadangan untuk pembangunan kota, atau sekedar program keindahan. (Cai, M., et al 2018). Keberadaan ruang terbuka hijau akan menciptakan iklim mikro, mengendalikan suhu udara sekitar dan mengurangi intensitas sinar matahari terhadap permukaan tanah (Peng, J., et al 2018). Dinamika ruang hijau sangat mempengaruhi tanah terbuka, lahan hutan dan badan air dapat meningkat masing-masing sebesar $80,63,25,05$, dan $1,88 \mathrm{~km} \mathrm{2}$. (Sun, R., \& Chen, L. 2017). Analisis NDVI untuk ruang terbuka hijau menunjukkan peningkatan yang signifikan yang terjadi selama periode waktu tertentu sesuai kondisi iklim dimana lahan mengalami kehilangan vegetasi 15,46 \% (Huang, H., et al 2017). Ruang terbuka mempunyai tujuan dan manfaat yang besar bagi keseimbangan, kelangsungan, kesehatan, kenyamanan, kelestarian, dan peningkatan kualitas lingkungan kota (Hakim dan Utomo, 2003).

Ruang terbuka hijau kota merupakan pertemuan antara sistem alam dan manusia pada wilayah perkotaan. Saat ini proporsinya semakin berkurang seiring peningkatan populasi dan kepadatan penduduk, sehingga mengakibatkan terganggunya keseimbangan antara kedua sistem tersebut (Rani, M et al., 2018). Untuk memperbaikinya serta meningkatkan kualitas lingkungan perkotaan secara umum, ruang terbuka hijau kota perlu dikembalikan dalam bentuk sistem agar dapat berperan optimal (Anguluri, R., \& Narayanan, P. 2017). Mempertahankan ruang terbuka perkotaan membutuhkan pendekatan sistem sosialekologis yang mempertimbangkan umpan balik kondisi ekologis dan kondisi sosial budaya penduduk, dimana Urban Ecosystem Services (UES) dapat meningkatkan ketahanan perkotaan pada kuantitas, kualitas, dan keragaman infrastruktur hijau yang dibangun (Calderón-Contreras, R., \& Quiroz-Rosas, L. E., 2017). Pembentukan sistem ruang terbuka hijau merupakan respon terhadap kebutuhan ruang terbuka hijau pada suatu wilayah perkotaan (Putri, P., \& Zain, A. F. 2010).

Fungsi RTH menurut Permendagri Nomor 1 Tahun 2007 dapat berfungsi secara ekologis, sosial/budaya, arsitektural, dan ekonomi. Secara ekologis RTH dapat meningkatkan kualitas air tanah, mencegah banjir, mengurangi polusi udara, dan menurunkan temperatur kota. Selain itu, penataan ruang terbuka hijau kota juga merupakan bagian strategi perencanaan kota untuk membatasi pembangunan serta mengatasi dampak 
ekologis berbagai aktivitas manusia terkait gangguan proses alam pada lingkungan perkotaan (Ditjentaru, 2008).

Penelitian ruang hijau telah didorong oleh minat yang muncul terhadap dampak keanekaragaman hayati dan fungsi ekosistem terhadap kehidupan di daerah perkotaan. Studi dari berbagai disiplin ilmu biofisik dan ilmu sosial menyelidiki interaksi yang menciptakan berbagai temuan terkait manfaat ruang hijau terhadap kehidupan perkotaan (Taylor, L., \& Hochuli, D. F., 2017).

Bentuk-bentuk RTH perkotaan yang berfungsi ekologis antara lain seperti sabuk hijau kota, hutan kota, taman botani, dan sempadan sungai (As-syakur, A. R., \& Adnyana, I. S, 2009). Sedangkan menurut; Kim, H. W., Kim, J. H., Li, W., Yang, P., \& Cao, Y. (2017), bahwa ruang daerah perkotaan dapat dikategorikan sebagai ruang hijau dan termasuk taman, pantai, taman kota/ruang terbuka, hutan kota serta padang rumput. Keberadaan ruang hijau di wilayah perumahan kota tidak hanya berkontribusi pada peningkatan kualitas visual ke area perumahan tetapi juga memberikan interaksi rekreasi dan sosial kepada penghuni perumahan (Mensah, C. A., Andres, L., Perera, U., \& Roji, A., 2016). Untuk mendukung program penataan RTH, maka diperlukan perhitungan luas lahan RTH suatu kota secara tepat melalui data penginderaan jauh yang kini banyak dimanfaatkan untuk pengukuran RTH (Irwan ZD, 2005).

Di wilayah pusat Kota Ambon terkait penataan Ruang Terbuka Hijau (RTH) mengalami berbagai kelemahan dari segi penataan pola ruang dan strategi penataan kota. Hal ini sangat terkait dengan realisasi kebijakan yang berlaku di bidang penataan kota yang memberikan dampak terhadap kondisi kenyamanan kota itu sendiri.

Di antara strategi tersebut adalah ruang terbuka hijau sebagai area resapan, ruang terbuka hijau sebagai pereduksi polusi, serta ruang terbuka hijau sebagai penurun temperatur udara. Untuk melihat sejauh mana pola ruang kota Ambon yang berhubungan dengan perencanaan ruang terbuka hijau (RTH) dan bagaimana dampak penataan RTH terkait indikator tingkat kehijauan secara spasial, maka diperlukan suatu kajian dan analisis pola ruang dan mengukur tingkat kehijauan menggunakan data citra satelit pada penataan pola ruang di kota Ambon, sehingga dapat diukur dampak yang nyata dari model spasial sesuai kritria dan indeks kenyamanan kota yang dibangun melalui hasil kajian dalam penelitian ini. Target lainnya untuk mendapatkan informasi mendasar dan terukur berdasarkan pendekatan metode Nilai dari indeks vegetasi hasil analisis citra satelit yang merupakan indikator tingkat kehijauan 
tanaman dalam hubungan dengan kandungan potensi karbon yang tersimpan pada berbagai jenis tanaman di kawasan Ruang Terbuka Hijau (RTH) di Kota Ambon.

\section{METODE PENELITIAN}

Menurut Purwadhi (2009), teknik untuk mencari penutupan lahan yang sudah diproses dengan penajaman berdasarkan komponen vegetasi (indeks vegetasi). Penajaman dengan membuat citra indeks vegetasi, yang pembuatannya dengan mengurangkan, menambah dan membandingkan nilai digital tiap saluran yang spektralnya berbeda.

Prahasta (2008) mengatakan dari beberapa wacana mengenai konsep indeks vegetasi, yang paling sering digunakan dan paling populer adalah NDVI (normalized difference vegetation index). Nilai index vegetasi ini dihitung sebagai rasio pantulan yang terukur dari band merah $(\mathrm{R})$ dan band Inframerah (NIR) pada spektrum gelombang elektromagnetik (Jochem O. Klompmaker., et al 2017).

Kedua band ini dipilih sebagai parameter indeks vegetasi karena hasil pengukurannya paling dipengaruhi oleh penyerapan klorofil daun atau vegetasi hijau. Secara umum formula NDVI ditulis dengan persamaan:
$" N D V I=(N I R-R) /(N I R+R) "$. (Ahmed, K. R., \& Akter, S., 2017).

Terkait pemetaan vegetasi di kawasan RTH pada sudut tata ruang dilakukan menggunakan sistem Informasi Geografis (SIG) menggunakan software ArcGis 10.1. Pengambilan titik plot vegetasi (tiang dan pohon) dilakukan dengan menggunakan GPS (Global Positioning System). Citra Landsat ETM-8 diolah menggunakan software Envi 4.7 dan Mapinfo 10.5 untuk penggabungan band data citra.

Metode yang digunakan dalam penelitian ini adalah integrasi antara klasifikasi penutup lahan menggunakan Metode Maksimum Likelihood, dan indeks vegetasi yaitu Normalized Difference Vegetation Index (NDVI). Sedangkan hasil akhir dalam penentuan kelas indeks vegetasi menggunakan kelas indeks tingkat kehijauan yang dikemukakan oleh Marwoto \& Ginting, (2009). 


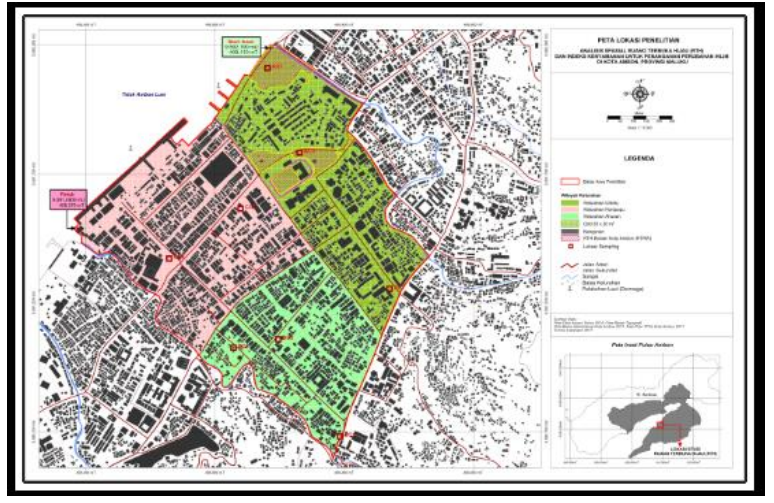

Gambar 1. Lokasi Penelitian RTH Kota Ambon

Tabel 1. Kelas Indeks Vegetasi (NDVI)

\begin{tabular}{|c|c|l|}
\hline NO & $\begin{array}{c}\text { NILAI INDEKS } \\
\text { VEGETASI }\end{array}$ & $\begin{array}{c}\text { TINGKAT } \\
\text { KEHIJAUAN }\end{array}$ \\
\hline 1 & $0.40-1$ & Tinggi \\
\hline 2 & $0.25-<0.40$ & Sedang \\
\hline 3 & $0.03-<0.25$ & Rendah \\
\hline 4 & $-1-0.03$ & Non Vegetasi \\
\hline
\end{tabular}

Sumber: Marwoto \& Ginting (2009)

\section{HASIL DAN PEMBAHASAN}

Ruang Terbuka Hijau (RTH) adalah area memanjang/jalur dan atau mengelompok, yang penggunaannya lebih bersifat terbuka, tempat tumbuh tanaman, baik yang tumbuh tanaman secara alamiah maupun yang sengaja ditanam. Ruang terbuka non hijau adalah ruang terbuka di wilayah perkotaan yang tidak termasuk dalam kategori RTH, berupa lahan yang diperkeras maupun yang berupa badan air. Kriteria untuk perencanaan RTH mengacu pada Permen PU No. 17/PRT/M/2009 tentang Pedoman Penyusunan RTRW Kota dan Permen PU

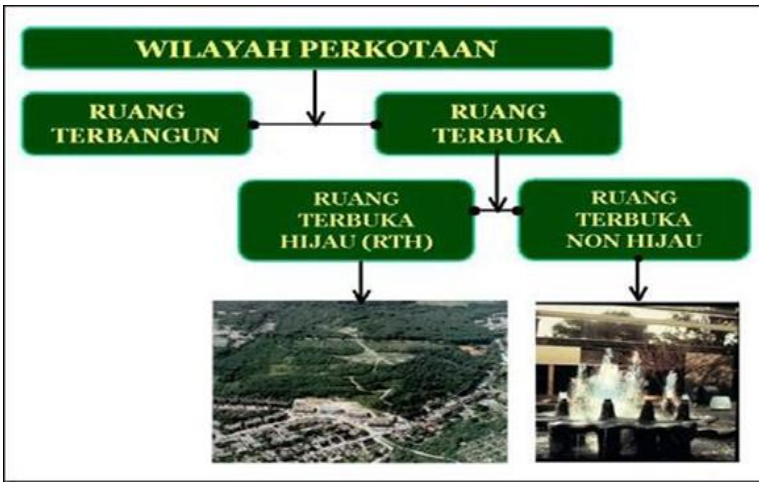

Gambar 2. Ruang Terbuka Publik (Open Space)

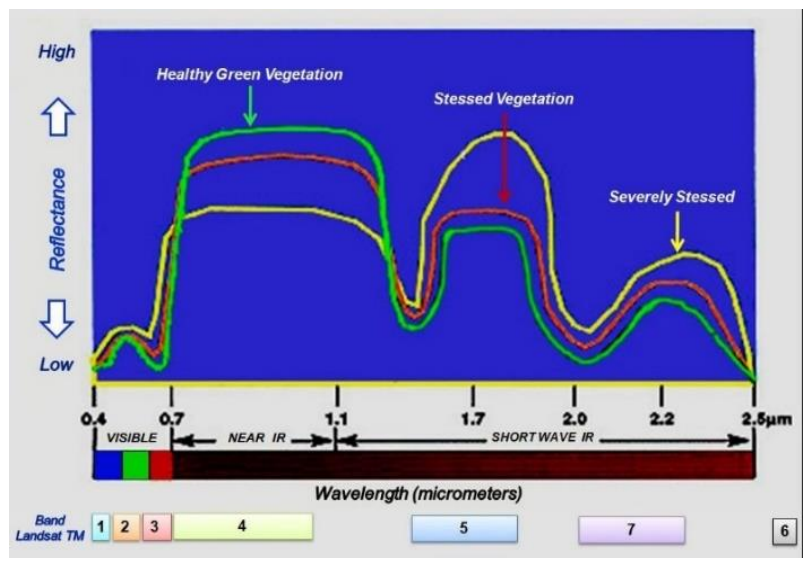

Gambar 3. Pantulan Spectral Vegetasi

No.05/PRT/M/2008 tentang Pedoman

Penyediaan dan Pemanfaatan Ruang Terbuka Hijau di Kawasan Perkotaan adalah;

1. Dialokasikan pada pusat-pusat pelayanan sesuai dengan hierarki taman yang akan direncanakan.

2. Memiliki jalan akses minimum berupa jalan lingkungan (untuk taman lingkungan, jalan kolektor untuk taman kecamatan dan taman kota).

3. Memperhatikan ketentuan ketentuan yang terkait dengan perencanaan RTH perkotaan. 
Batasan lokasi RTH pada sudut ruang Kota Ambon dalam penelitian ini memiliki areal seluas $\pm 1.115 .900 \mathrm{~m}^{2}$ atau 111,59 ha meliputi Kelurahan Honipopu $\pm 436.300 \mathrm{~m}^{2}$ atau 43,63 ha; Kelurahan Ahusen, $\pm 286.500 \mathrm{~m}^{2}$ atau 28,65 ha dan Kelurahan Uritetu $\pm 393.100 \mathrm{~m}^{2}$ atau 39,31 ha. Luas sembilan lokasi sampling $25.408,59 \mathrm{~m}^{2}$ atau 2,54 ha atau 2,28\% kawasan RTH dari luas wilayah ketiga Kelurahan tersebut. Rencana Tata Ruang Wilayah (RTRW) Kota Ambon telah disahkan sebagai Peraturan Daerah Kota Ambon No. 24 tahun 2012. Kebijakan yang perlu diacu diantaranya yang cukup penting adalah Rencana Struktur Ruang dan Rencana Pola Ruang. Sesuai Rencana Detail Tata Ruang Kota Ambon (RDTR) Kota Ambon Tahun 2012-2032.

\section{- Luas Tutupan Vegetasi Pada Sudut RTH Kota Ambon}

Kegiatan inventarisasi dan pengukuran tegakan vegetasi berdasarkan tipe tutupan lahan pada sudut RTH Kota Ambon dilakukan dengan menentukan lokasi dan luasan area sampling. Selain kegiatan mengidentifikasi dan mengukur vegetasi tumbuhan bawah (rerumputan dan pancang) dan vegetasi tingkat tiang dan pohon di lapangan. Nilai pengukuran vegetasi bisa dilakukan dengan pendekatan skala plot untuk mengetahui luas jenis tanaman berdasarkan tingkatan jenis mulai dari vegetasi tumbuhan bawah, vegetasi tingkat pancang, tingkat tiang dan tingkat pohon (Hatulesila Y, 2008). Pada kegiatan penelitian ini analisis terhadap tipe tutupan lahan secara spasial dilakukan melalui pendekatan pembuatan plot sampling untuk menghitung keliling tajuk dan luasan tutupan tajuk, sehingga dapat diukur penutupan vegetasi skala plot, seperti disajikan pada tabel dan gambar berikut.

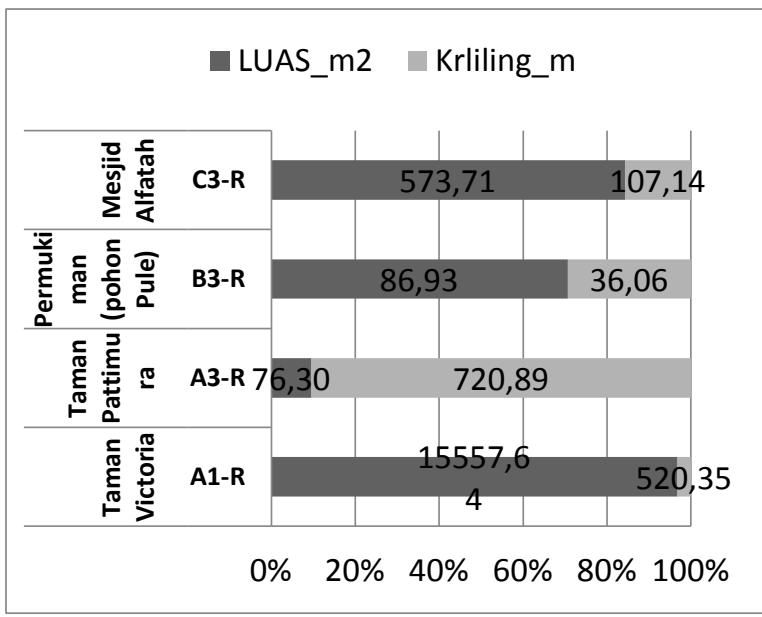

Gambar 4. Nilai Persentase Luas Tutupan dan Keliling Rerumputan

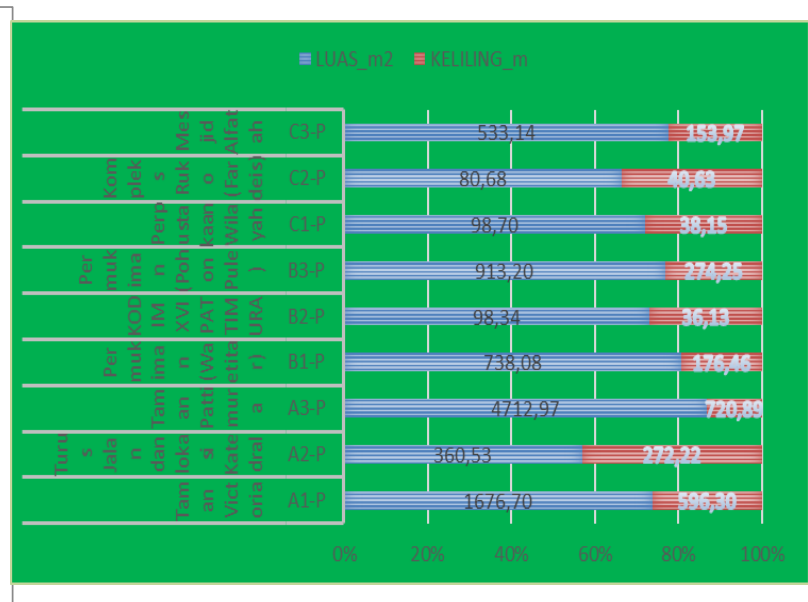

Gambar 5. Nilai Persentase Luas Tutupan dan Keliling 
Tabel 2. Persentase Luas Tutupan Vegetasi Pada Lokasi Sampling

\begin{tabular}{|c|c|c|c|c|c|c|}
\hline BT & $\mathbf{L S}$ & Lokasi Sampling & Vegetasi & $\begin{array}{c}\text { Luas } \\
\text { Tutupan } \\
\text { Tajuk (m2) } \\
\end{array}$ & $\begin{array}{c}\text { Keliling } \\
\text { Tajuk } \\
\text { (m) }\end{array}$ & $\begin{array}{c}\text { Presentase } \\
(\%)\end{array}$ \\
\hline 128,1817 & $-3,69$ & Taman Victoria & Rerumputan & 15557,64 & 520,35 & 95,48 \\
\hline 128,1831 & $-3,6936$ & Taman Pattimura & Rerumputan & 86,93 & 36,06 & 0,47 \\
\hline 128,1803 & $-3,6997$ & $\begin{array}{l}\text { Permukiman Warga } \\
\text { (Pohon Pule) }\end{array}$ & Rerumputan & 76,30 & 720,89 & 0,53 \\
\hline 128,178 & $-3,6965$ & Mesjid Raya Alfatah & Rerumputan & 573,71 & 107,14 & 3,52 \\
\hline & & s Rerumputan & & 16294,59 & 1384,44 & 100,00 \\
\hline 128,1857 & $-3,6976$ & Taman Victoria & Pepohonan & 1676,70 & 596,30 & 18,20 \\
\hline 128,1825 & $-3,693$ & $\begin{array}{c}\text { Turus Jalan Pattimura } \\
\text { \& Katedral }\end{array}$ & Pepohonan & 360,53 & 272,22 & 3,91 \\
\hline 128,1836 & $-3,6932$ & Taman Pattimura & Pepohonan & 4712,97 & 720,89 & 51,16 \\
\hline 128,184 & $-3,7024$ & $\begin{array}{c}\text { KODIM TNI XVI } \\
\text { PATTIMURA }\end{array}$ & Pepohonan & 98,34 & 36,13 & 8,01 \\
\hline 128,184 & $-3,7027$ & $\begin{array}{c}\text { Permukiman Warga } \\
\text { (Waetitar) }\end{array}$ & Pepohonan & 738,08 & 176,46 & 1,07 \\
\hline 128,1802 & $-3,6997$ & $\begin{array}{l}\text { Permukiman Warga } \\
\text { (Pohon Pule) }\end{array}$ & Pepohonan & 913,20 & 274,25 & 9,91 \\
\hline 128,1805 & $-3,6948$ & $\begin{array}{c}\text { Perpustakaan } \\
\text { Wilayah }\end{array}$ & Pepohonan & 98,70 & 38,15 & 1,07 \\
\hline 128,1821 & $-3,6961$ & $\begin{array}{c}\text { Kompleks Ruko } \\
\text { (Fardeis) }\end{array}$ & Pepohonan & 80,68 & 40,63 & 0,88 \\
\hline 128,1781 & $-3,6968$ & Mesjid Raya Alfatah & Pepohonan & 533,14 & 153,97 & 18,20 \\
\hline \multicolumn{4}{|c|}{ Luas Pepohonan } & $\mathbf{9 2 1 2 , 3 5}$ & 2309,00 & 100,00 \\
\hline \multicolumn{4}{|c|}{ Luas Total $\left(\mathbf{m}^{2}\right)$} & 25506,94 & 3693,44 & \\
\hline \multicolumn{4}{|r|}{ Luas (Ha) } & 2,55 & & \\
\hline
\end{tabular}

Kegiatan analisis tutupan vegetasi pada empat lokasi sampling rumput menunjukan bahwa luasan tertinggi adalah pada lokasi taman victoria dengan tutupan vegetasi sebesar 15.557,64 $\mathrm{m}^{2}$ dengan keliling $520,35 \mathrm{~m}$ atau sebesar 95,48\% dan terendah pada taman Pattimura dengan luas tutupan vegetasi 86,93 $\mathrm{m}^{2}$ dan keliling 36,06 $\mathrm{m}$ atau hanya sebesar $0,47 \%$. Sedangkan vegetasi tingkat tiang dan pohon untuk lokasi Taman Pattimura dengan tutupan vegetasi tertinggi sebesar 4.712,97 $\mathrm{m}^{2}$ dengan keliling 720,89 m atau $51,16 \%$ dan terendah pada lokasi kompleks ruko Fardeis dengan luas tutupan vegetasi sebesar $80,68 \mathrm{~m}^{2}$ dan keliling 40,63 m sebesar 0,88\%. Hasil pengukuran tutupan vegetasi menggunakan analisis spasial untuk sembilan lokasi sampling dimana tutupan vegetasi rerumputan menempati keseluruhan luas sebesar $16.294,59 \mathrm{~m}^{2}$ sedangkan vegetasi pohon dengan luas $9.212,35 \mathrm{~m}^{2}$ sehingga luasan vegetasi untuk sembilan lokasi sampling sebesar 25.506,94 $\mathrm{m}^{2}$ atau 2,55 ha. Jenis dan jumlah vegetasi pada tegakan campuran berbeda dengan tegakan monokultur memiliki kerapatan pohon berbeda karena hal ini terkait luas tajuk, 
tinggi tanaman, ukuran diameter pohon dan faktor fisiologi tanaman yang memiliki pertumbuhan sangat cepat (Mardiatmoko et al, 2012).

Luas lokasi penelitian meliputi tiga administratif kelurahan masing masing Kelurahan Honipopu, Kelurahan Ahusen dan Kelurahan Uritetu dengan luas $1.115 .900 \mathrm{~m}^{2}$ atau 111,6 ha sebagai lokasi keseluruhan luas kawasan RTH Kota Ambon. Sedangkan lokasi sampling sembilan lokasi pada kawasan RTH seluas 2,55 ha, berarti hanya seluas $2,28 \%$ dari total luas lokasi penelitian sedangkan lokasi tutupan lahan vegetasi keseluruhan hasil analisis NDVI seluas 61,58 ha. Kondisi tutupan lahan pada RTH kota Ambon, sedangkan kebutuhan Ruang Terbuka Hijau jika didasarkan pada persentase luas wilayah berdasarkan Undang-undang penataan ruang yaitu sebesar $30 \%$. Sehingga jika luas total kawasan RTH dari ketiga Kelurahan seluas 111,6 ha dengan keberadaan hasil analisis NDVI untuk tutupan vegetasi lokasi penelitian sebesar 61,58 ha telah melebihi 30\% kawasan RTH sesuai amanat Undang-Undang Penataan Ruang.

\section{Hasil Analisis NDVI (Normalized Difference Vegetation Index) RTH Kota Ambon}

Nilai NDVI (Normalized Difference Vegetation Index) merupakan suatu nilai hasil pengolahan indeks vegetasi dari citra satelit kanal infra merah dan kanal merah yang menunjukkan tingkat konsentrasi klorofil daun yang berkorelasi dengan kerapatan vegetasi berdasarkan nilai spektral pada setiap piksel. Menurut (Purwadhi F.S.H dan T. B.Sanjoto, 2009) nilai NDVI yang mencerminkan kondisi vegetasi berkisar antara 0,1 sampai 0,6 dengan nilai NDVI yang tinggi mempunyai tingkat kehijauan yang tinggi. Indeks vegetasi pada penelitian ini digunakan untuk mengetahui persentase tutupan hijau yang dapat diasumsikan sebagai ruang terbuka hijau dari citra LANDSAT- 8, sehingga diharapkan dapat mencerminkan kondisi yang sebenarnya di daerah penelitian.

Berdasarkan hasil analisis yang dilakukan menunjukan bahwa semakin tinggi nilai NDVI maka semakin tinggi nilai persentase tutupan hijau, hal ini menunjukan bahwa ada hubungan yang erat antara nilai indeks vegetasi dengan persentase tutupan hijau di daerah penelitian.

Adapun kelas tutupan hijauan hasil analisis NDVI lokasi RTH Kota Ambon digambarkan pada Tabel 3.

Ruang terbuka hijau (RTH) sebagai ruang alami merupakan bagian yang sangat penting bagi suatu kota berkaitan dengan penanggulangan berbagai masalah lingkungan. 
Hasil penelitian ini diharapkan mampu memberikan informasi mengenai perubahan luasan RTH di kota Ambon berkaitan dengan penetapan kelas tutupan lahan yang dapat mewakili sebaran tutupan lahan hasil interpretasi Citra Satelit Landsat - 8 dan penentuan klasifikasi berdasarkan indeks kerapatan hasil analisis NDVI terhadap

Tabel 3. Kelas Tutupan Hijauan NDVI

\begin{tabular}{|c|l|c|l|}
\multicolumn{5}{c}{ Kota Ambon } \\
\hline Kelas & Warna & Nilai NDVI & Keterangan \\
\hline I & & $0,00-0,05$ & Sangat Jarang \\
\hline II & & $0,05-0,10$ & Agak Jarang \\
\hline III & & $0,10-0,15$ & Jarang \\
\hline IV & & $0,15-0,20$ & Agak Sedang \\
\hline V & & $0,20-0,25$ & Sedang \\
\hline VI & & $0,25-0,30$ & Agak Rapat \\
\hline VII & & $0,30-0,35$ & Rapat \\
\hline VIII & & $0,35-0,40$ & Sangat Rapat \\
\hline \multicolumn{3}{|l}{} \\
\hline
\end{tabular}

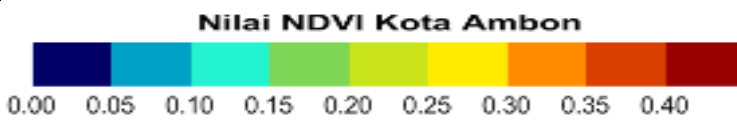

Sebaran tutupan vegetasi baik tumbuhan bawah maupun tingkat pohon pada sembilan lokasi sampling di kawasan RTH Kota Ambon, hasil perhitungan NDVI dari data Landsat 8 tahun 2017 menunjukan bahwa secara umum pantulan nilai spektral hasil analisis citra infrared masih ditemukan jenis tanaman yang memiliki nilai NDVI yang tinggi (warna merah) rengs nilai $0,35-0,40$ dengan kategori sangat rapat, namun selain itu keseluruhan lokasi penelitian untuk keberadaan RTH di kawasan sudut kota Ambon. Hasil analisis tutupan lahan berdasarkan penetapan delapan sebaran kelas tutupan hijauan hasil analisis NDVI pada kawasan RTH Kota Ambon disajikan pada tabel dan gambar berikut:

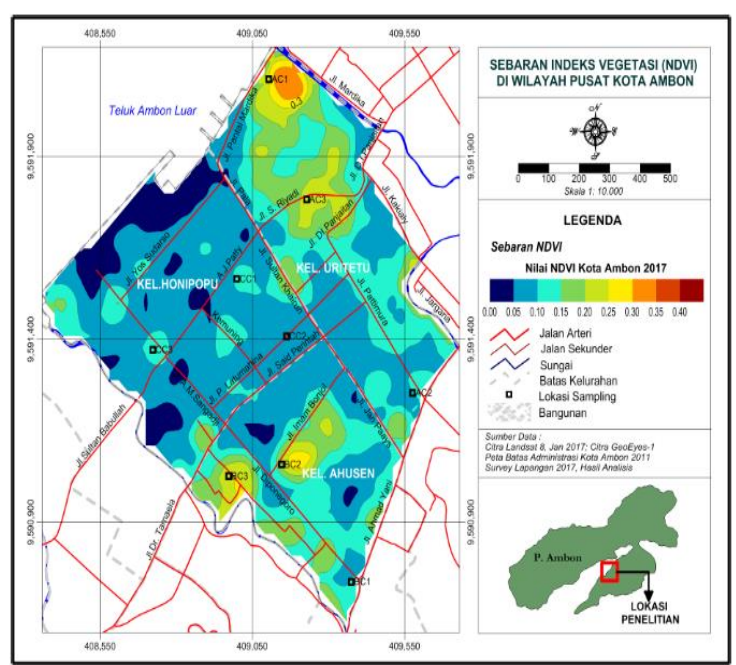

Gambar. 6. Peta NDVI RTH Kota Ambon

ada pula nilai NDVI yang cukup rendah (warna biru) kisaran nilai $0,00-0,05$ umumnya menunjukkan kelas non vegetasi dengan kategori sangat jarang dan terlihat sangat mendominasi lokasi RTH Kota Ambon. Perbedaan nilai ini dapat dilihat pada Persentase luas tutupan lahan hasil analisis NDVI pada tabel dan gambar berikut. 
Tabel 4. Sebaran NDVI Berdasarkan Luasan Tutupan Lahan RTH Kota Ambon

\begin{tabular}{|c|c|c|c|}
\hline NILAI NDVI 2017-01 & AREA_Ha & X & Y \\
\hline $0.00-0.05$ LK & 4,40 & 128,1780 & $-3,6935$ \\
\hline $0.00-0.05$ B & 3,30 & 128,1762 & $-3,6942$ \\
\hline $0.05-0.10 \mathrm{~B}$ & 22,00 & 128,1798 & $-3,6934$ \\
\hline $0.05-0.10 \mathrm{~V}$ & 28,32 & 128,1809 & $-3,6954$ \\
\hline $0.10-0.15 \mathrm{~B}$ & 9,71 & 128,1822 & $-3,7001$ \\
\hline $0.10-0.15 \mathrm{~V}$ & 18,06 & 128,1811 & $-3,7003$ \\
\hline $0.15-0.20 \mathrm{~B}$ & 3,78 & 128,1827 & $-3,6936$ \\
\hline $0.15-0.20 \mathrm{~V}$ & 9,45 & 128,1813 & $-3,6919$ \\
\hline $0.20-0.25 \mathrm{~B}$ & 0,76 & 128,1831 & $-3,6925$ \\
\hline $0.20-0.25 \mathrm{~V}$ & 4,13 & 128,1831 & $-3,6925$ \\
\hline $0.25-0.30 \mathrm{~B}$ & 0,08 & 128,1823 & $-3,6993$ \\
\hline $0.25-0.30 \mathrm{~V}$ & 0,93 & 128,1816 & $-3,6899$ \\
\hline $0.30-0.35 \mathrm{~B}$ & 0,00 & 128,1824 & $-3,6902$ \\
\hline $0.30-0.35 \mathrm{~V}$ & 0,69 & 128,1821 & $-3,6899$ \\
\hline
\end{tabular}

Ket : LK = Lahan Kosong, V=Vegetasi dan B = Bangunan

Sumber : Olah Data Penelitian 2017

Tabel 5. Luas Tutupan Lahan Analisis NDVI

\begin{tabular}{|l|r|r|}
\hline \multicolumn{1}{|c|}{ NDVI 2017 } & NDVI & Luas_Ha \\
\hline Lahan Kosong & $0.00-0.05$ & 4,40 \\
\hline Vegetasi & $0.05-0.35$ & 61,58 \\
\hline Bangunan & $0.00-0.30$ & 39,63 \\
\hline \multicolumn{2}{r}{ Total Luas } & 105,61 \\
\hline
\end{tabular}

Sumber : Olah Data Penelitian 2017

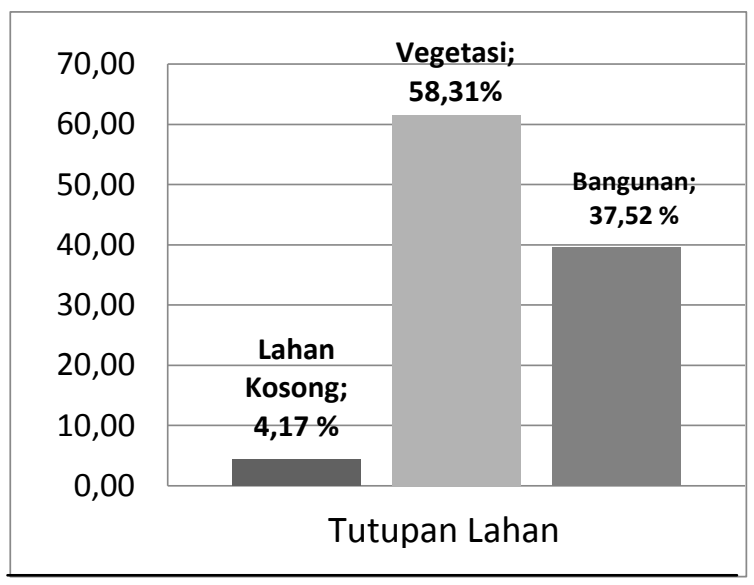

Gambar 7. Persentase Tutupan Lahan Analisis NDVI

Data Tabel tersebut di atas menunjukkan bahwa 61,58 ha atau 58,31\%, diikuti oleh tutupan Bangunan dengan luas 39,63 ha atau 37, $52 \%$ dan lahan kosong menempati urutan terakhir dengan luas 4,40 ha atau 4,17\% dibandingkan dengan tutupan vegetasi dan bangunan. Dengan demikian Persentase luas tutupan vegetasi pada sembilan lokasi sampling telah menunjukan bahwa semakin 
besar tutupan vegetasi akan memberikan suasana kenyamanan untuk wilayah kota Ambon dan akan mempengaruhi keberadaan suhu mikro kota Ambon.

Perbedaan jenis vegetasi menentukan kondisi iklim mikro pada masing-masing lokasi. Hal ini disebabkan oleh perbedaan karakteristik masingmasing jenis vegetasi dalam menyerap ataupun memantulkan energi matahari yang diterimanya. Menurut Hayati, dkk. (2013), kondisi vegetasi dengan kerapatan pohon yang tinggi dan luas penutupan lahan akan mempengaruhi kondisi iklim mikro (suhu udara dan kelembaban udara), kemudian akan menentukan tingkat kenyamanan suatu lingkungan.

\section{KESIMPULAN DAN SARAN}

\section{Kesimpulan}

1. Batasan lokasi RTH pada ruang Kota Ambon pada penelitian ini memiliki areal seluas \pm $1.115 .900 \mathrm{~m}^{2}$ atau 111,59 ha meliputi Kelurahan Honipopu $\pm 436.300 \mathrm{~m}^{2}$ atau 43,63 ha; Kelurahan Ahusen, $\pm 286.500 \mathrm{~m}^{2}$ atau 28,65 ha dan Kelurahan Uritetu $\pm 393.100 \mathrm{~m}^{2}$ atau 39,31 ha. Luas sembilan lokasi sampling $25,408.59 \mathrm{~m}^{2}$ atau 2,54 ha atau 2,28\% kawasan RTH dari luas wilayah ketiga Kelurahan tersebut.

\section{DAFTAR PUSTAKA :}

Ahmed, K. R., \& Akter, S. 2017. Analysis of landcover change in southwest Bengal delta due to floods by NDVI, NDWI and $\mathrm{K}$-means cluster with Landsat multispectral surface reflectance satellite data. Remote Sensing Applications: Society
2. Tutupan vegetasi untuk lokasi sampling tumbuhan bawah (rerumputan dan pancang) memiliki luas tutupan tajuk adalah $16.316,98 \mathrm{~m}^{2}$ atau 1,63 ha sedangkan pepohonan (tiang dan pohon) memiliki luas tutupan tajuk adalah $5.744,73 \mathrm{~m}^{2}$ atau 0,57 ha.

3. Analisis NDVI menunjukkan bahwa tingkat kehijauan terkait penutupan vegetasi pada kisaran sebaran nilai indeks vegetasi 0,05 0,35 didominasi oleh tutupan vegetasi seluas 61,58 ha atau 58,31\% menempati luasan terbesar, diikuti lahan terbangun dengan sebaran nilai indeks vegetasi $0,00-0,35$ seluas 39,63 ha atau $37,52 \%$ dan lahan kosong dengan sebaran nilai indeks vegetasi $0,00-0,05$ seluas 4,40 ha atau $4,17 \%$ untuk keseluruhan lokasi penelitian.

\section{Saran}

Perlu dilakukan penelitian lanjutan terkait indeks polusi udara di Kota Ambon, yang berkaitan dengan nilai indeks kehijauan tanaman di RTH Kota Ambon

Hakim, R. dan H. Utomo. 2003. Komponen Perancangan Arsitektur Lansekap. Prinsip, Unsur dan Aplikasi Desain.Buku. Bumi Aksara. Jakarta. 287 p.

Hakim, Rustam Ir. dan Utomo, Hardi Ir. 2003. 
and Environment, 8, 168-181.

Anguluri, R., \& Narayanan, P. 2017. Role of green space in urban planning: Outlook towards smart cities. Urban Forestry \& Urban Greening, 25, 58-65.

As-syakur, A. R., \& Adnyana, I. S. 2009. Analisis indeks vegetasi menggunakan citra ALOS/AVNIR-2 dan sistem informasi geografi (SIG) untuk evaluasi tata ruang kota Denpasar. Bumi Lestari Journal of Environment, 9(1), 1-11.

Cai, M., Ren, C., Xu, Y., Lau, K. K. L., \& Wang, R. 2018. Investigating the relationship between local climate zone and land surface temperature using an improved WUDAPT methodology-A case study of Yangtze River Delta, China. Urban climate, 24, 485-502.

Calderón-Contreras, R., \& Quiroz-Rosas, L. E. 2017. Analysing scale, quality and diversity of green infrastructure and the provision of Urban Ecosystem Services: A case from Mexico City. Ecosystem services, 23, 127-137.

FEBRIANTI, Nur; SOFAN, Parwati. 2014, Ruang terbuka hijau di DKI Jakarta berdasarkan analisis spasial dan spektral data landsat 8. Sumber, 100: 11.5-12.5.

Ditjentaru. 2008. Peraturan Menteri Pekerjaan Umum Nomor: 05/PRT/M/2008 tentang Pedoman Penyediaan dan Pemanfaatan Ruang Terbuka Hijau di Kawasan Perkotaan. Departemen Pekerjaan Umum.

Klompmaker, J. O., Hoek, G., Bloemsma, L. D., Gehring, U., Strak, M., Wijga, A. H., ... \& Janssen, N. A. 2017. Green space definition affects associations of green space with overweight and physical activity. Environmental research, 160, 531540.

Mardiatmoko, G., Silaya, T. M., \& Hatulesila, J. W. 2012. Study on Application of Geographical Information System (Gis) for Establishment of Biomass Classification to Support Implementation of Clean Development Mechanism. AGRIVITA, Journal of Agricultural Science, 34(1), 1-6.

Mensah, C. A., Andres, L., Perera, U., \& Roji, A. 2016. Enhancing quality of life through the lens of green spaces: A systematic review
Komponen Perancangan Arsitektur Lansekap Prinsip - Unsur dan Aplikasi Disain. Penerbit Bumi Aksara. Jakarta.

Hatulesila, Y. 2008. Bentuk-Bentuk Penggunaan dan Produktivitas Lahan Sistem Dusun di Kecamatan Leihitu Kabupaten Maluku Tengah [Land Use Forms and Productivity of Dusun Systems, in Leihitu sub-district, Maluku Tengah District.], 61 pp. 2008. $\mathrm{PhD}$ Thesis. Tesis Fakultas Kehutanan IPB, Bogor.

Hayati. J. Santun. R. P. dan Siti. N. 2013. Pengembangan ruang terbuka hijau dengan pendekatan kotahijau di Kota Kandangan.Jurnal Tata Loka. 14(4):306-316.

Huang, H., Chen, Y., Clinton, N., Wang, J., Wang, X., Liu, C., ... \& Zhu, Z. 2017. Mapping major land cover dynamics in Beijing using all Landsat images in Google Earth Engine. Remote Sensing of Environment, 202, 166-176.

Irwan ZD. 2005. Tantangan Lingkungan dan Lansekap Hutan Kota. Bumi Aksara. Jakarta.

Kim, H. W., Kim, J. H., Li, W., Yang, P., \& Cao, Y. 2017. Exploring the impact of green space health on runoff reduction using NDVI. Urban Forestry \& Urban Greening, 28, 81-87.

Purwadhi F.S.H dan T. B.Sanjoto, 2009. Pengantar Interpretasi Citra Penginderaan Jauh. Pusat Data Penginderaan Jauh Lembaga Penerbangan dan Antariksa Nasional dan Jurusan Geografi Universitas Semarang. Semarang.

Putri, P., \& Zain, A. F. 2010. Analisis Spasial dan Temporal Perubahan Luas Ruang Terbuka Hijau di Kota Bandung. Jurnal Lanskap Indonesia, 2(2).

Rani, M., Kumar, P., Pandey, P. C., Srivastava, P. K., Chaudhary, B. S., Tomar, V., \& Mandal, V. P. 2018. Multi-temporal NDVI and surface temperature analysis for Urban Heat Island inbuilt surrounding of sub-humid region: A case study of two 
approach. International Journal of Wellbeing, 6(1).

Peng, J., Jia, J., Liu, Y., Li, H., \& Wu, J. 2018. Seasonal contrast of the dominant factors for spatial distribution of land surface temperature in urban areas. Remote sensing of environment, 215, 255-267.

Prahasta, E, 2008. Remote Sensing Praktis Penginderaan Jauh dan Pengolahan Citra Digital dengan Perangkat Lunak ER Mapper. Penerbit Informatika. Bandung. geographical regions. Remote Sensing Applications: Society and Environment, 10, 163-172.

Sun, R., \& Chen, L. 2017. Effects of green space dynamics on urban heat islands: Mitigation and diversification. Ecosystem services, 23, 38-46.

Taylor, L., \& Hochuli, D. F. 2017. Defining greenspace: Multiple uses across multiple disciplines.Landscape and Urban Planning, 158, 25-38. 